\title{
The Development of Adobe Premiere-Based Learning Media in Moodboard Making Material in SMKN 3 Malang
}

\author{
Ari Aprilia ${ }^{1}$, Nurul Aini ${ }^{2}$, Sri Eko Puji Rahayu ${ }^{3}$
}

\author{
${ }^{1,2,3}$ Universitas Negeri Malang \\ *Corresponding author Email: nurul.aini.ft@um.ac.id
}

\begin{abstract}
This development research is aimed to create a product in a form of video tutorial media in fashion design subject. This media is focusing on the material of casual fashion moodboard making in accordance with the basic competency 3.6, 2013 curriculum. This media is produced in a form of compact disk (CD). The development procedure used is ADDIE model. The procedure consists of five steps, they are: (1) analysis, (2) design, (3) development, (4) implementation, and (5) evaluation. The result of validation and test shows that the learning media is very valid and good to use with the feasibility test's result of (1) validation of material's expert is $79.41 \%$, (2) validation of media's expert is $97.61 \%$, and (3) trial (students) is $90 \%$. The recommendation for the next development is to make adobe flash-based interactive multimedia using broader material, and to utilize education's forum as MGMP of fashion designer to introduce the product to the vocational high school's students in Malang.
\end{abstract}

Keywords: media development, adobe premiere, moodboard making

\section{INTRODUCTION}

Education has an important role to improve human resource quality. Conventional learning method that is applied by the teachers in teaching and learning process is less attractive towards students' attention; in this method, the teacher does not ask the students to be actively involved in the learning process. According to the field survey on January 152018 , supporting media used by the teacher during the learning process was moodboard making material that was limited in the using of text book and power point, therefore it was less attractive towards students' attention, as a result the students got difficulty in comprehending the material. In order to make an effective teaching and learning process, it needs a media that fits into students' character.

Learning media is a medium someone used to transfer a message or learning material. Video media of learning process is a media or supporting tool that consists of learning messages. Learning of Moodboard making material is one of scientific and technology development that is very influential towards the arrangement and implementation of learning strategy. Moodboard is one of materials in fashion design subject that is taught in SMKN 3 Malang. It is a media; can be in a form of board, book, and catalog that consists of a collection of pictures and themes that someone wants to create. This research is using development model of ADDIE. This research was conducted in SMKN 3 Malang.

"The word media comes from Latin language and is a plural form of medium word that literally means medium, media is a medium of a message from sender to the receiver (Sadiman, 2012:6). Media of learning is a tool that physically can be used to transfer a material to the students in order to ease teaching and learning process.

Adobe Premiere Pro is one of applications that can be used for video editing. This program can combine text, picture, video, and audio and also give an effect therefore the video made can be better in result. Adobe Premiere Pro is mostly chosen application by video editor because the editing skill is better and the result of video is smoother. Moodboard is an inspirational board that consists of designer's idea and creativity inside shown through picture, color, and other forms that is made in one media in a board formed with particular size. The purpose is the design made is not out of theme or customer's demand.

Fashion Design subject in SMKN3 Malang is a subject learning about technique of designing sketch. Materials in fashion design is pretty much, therefore it is divided into some materials given in some meetings with quality and level of difficulty that has been customized with students' processing time (beginner). The teacher divided the process of design making into 6 , they are: basic design of fashion, body anatomy material, color material, story board making material, and mood board making material.

\section{METHOD}

This research is using development research or wellknown as Research and Development (R\&D). It is a research method that is used to produce particular product and to test the product's effectiveness. The orientation of this research and development is a tutorial product that can be used and be accessed at anytime easily. The method used in this research and development is ADDIE model. 
According to Molenda (2003), some steps of the research and development using ADDIE model consist of: (1) Analysis, (2) Design, (3) Development, (4) Implementation, and (5) Evaluation.

\section{RESULTS AND DISCUSSION}

\section{Results}

The technique of data collection in the media development consists of validation and trial. The result of the data is the data from validation of material expert, media expert, and questionnaire filled by the respondents (students). The media expert is lecturer of education Faculty, State university of Malang that teaches fashion design subject. Each of media experts and material experts consists of 1 person. Validation process of material experts was conducted three times on July 1-12 2018, while media experts need one time on July 152019.

The trial was conducted to students of XI class majoring Fashion Design in SMKN3 Malang that have received moodboard making subject. This class is consisting of 3 classes that are divided into 2 , which is 1 design class and 2 regular classes. On this trial, the researcher used 1 class that consisted of 34 students; it was in accordance with ADDIE development model in trial phase, by using small class trial. The trial was conducted on July 162019 by explaining a little bit about media and its function, spreading questionnaire, and showing media that has been made in front of the students using an LCD. After conducting trial on the students, the researcher got the result of questionnaire, and also criticsm and suggestion from the respondents (students).

After conducting assessment on material expert, media expert, and trial, the data was obtained. Then, the data was processed and analyzed based on each aspect.

In part of data analysis of material expert. According to the data of media expert's assessment that consists of content, language, and presentation feasibilities, it obtained score for $79.41 \%$. It can be concluded that according to material expert; this media is very valid qualified.

In media expert's assessment, the result of data analysis was explained through questionnaire that has been filled, therefore it obtained data and also criticism and suggestion. According to the data that covers software engineering, learning design, and visual communication, it obtained score for $97,61 \%$. So, it can be concluded that according to this media expert, this media is very valid qualified.

From data analysis obtained from respondent's trial (students), video media of moodboard making tutorial got score $90 \%$ from the result of trial calculation with 20 questions consisting of 9 aspects covering functions of attention, affective, cognitive, compensatory, material, time duration, video presentation format, type of material, technical provision, and sound effect. Based on the result of the data, video media of moodboard making tutorial is very valid qualified.
Video media of moodboard making tutorial has been through several revisions because it needs experts 'feasibility before tested to the students. Product's feasibility is in accordance with experts 'suggestion in order to minimize some mistakes and maximize media's feasibility.

\section{Discussion}

The results of the adobe premiere-based video learning media validation results show that the learning media is very valid and feasible to use with the results of the percentage of eligibility as follows: (1) $79.41 \%$ material expert, in the material expert validation, validation is done 3 times (2) media expert $97.61 \%$ in the validation of media experts, validation is done 1 time.

Based on the trial results of this adobe premiere-based video tutorial learning media, it shows that the instructional media is very feasible to use with the results of the percentage of eligibility of $90 \%$. The results of the study can be said that the data is very feasible, according to Arikunto (2013: 285) in the quantitative meaning of Likert scale data.

Based on the results of the validation and testing of the product developed, several strengths and weaknesses were found. The advantages possessed by this learning media are: (1) this media can be stored on students' cellphones so that it can be played whenever needed. (2) this media is easily shared through various applications. (3) video media can be paused at any desired scene. (4) This media can save student learning time and add more interest and can provoke student creativity to create a moodboard.

Besides the advantages mentioned above, there are some weaknesses in this learning media. These weaknesses are: (1) the material on video media is incomplete and detailed due to the short video duration (2) video media is not accompanied by bibliography (3) video media is not interactive and is one-way learning.

\section{CONCLUSION}

The development of learning media is aimed to develop video media of tutorial in fashion design making subject in SMKN3 Malang. Furthermore, it gives reference related to the subject of moodboard making, therefore it makes the teacher and students at ease in conducting teaching and learning process. The importance of this media making can be seen from the result of observation, where the students are interested in learning using video better than reading books. Besides, this media can ease the students in learning the material of moodboard making.

This media is still in a form of video tutorial which means that it is not an interactive multimedia yet; this tutorial video media can be used as supporting material when the researcher want to make adobe flash teaching material, video as supporting and evaluation question. In the future, it will be better not only to use this media offline, but also online. The next development related to fashion design 
material will be better not only use one material only, but using more.

\section{REFERENCES}

[1] Arikunto, Suharsimi. 2013. Prosedur Penelitian, Suatu Pendekatan Praktik. Jakarta: PT Rineka Cipta.

[2] Azhar Arsyad. (2013). Media Pembelajaran. Jakarta : PT. Raja Grafindo Persada

[3] BSNP. (2007). Buletin edisi 01 bsnp. (online). Tersedia : www.bsnp-Indonesia.org>buletin [20 maret 19].

[4] Education Bureau. 2011. 3 Fashion Design Basics. Technology and Living (Secondary 46).

[5] KBBI. 2001. Pengertian Video (http://kbbi.kata.web.id video/diakses/2018/04/12/ 18.WIB)

[6] Sugiyono. 2009. Metode Penelitian Kuantitatif, Kualitatif dan R\&D. Bandung: Alfabeta, cv.

[7] Sukiman. 2012. Pengembangan Media Pembelajaran. Yogyakarta : Pedagogia.

[8] Tatham, Caroline \& Seaman, Julian. 2003. Fahion Design Course. New York: Quato Inc.

[9] Wahono, Romi, Satria. (2006). Aspek dam Kriteria Penilaian Media Pembelajaran. (online). Tersedia http://romisatriawahono.net/2006/06/21/aspekdan-kriteria-penilaian-media-pembelajaran/. [13 April 2018]. 